\title{
An ethnobotanical survey and antifungal activity of Piper guineense used for the treatment of fungal infections in West-African traditional medicine
}

\section{Mgbeahuruike, Eunice Ego}

2019-01-30

Mgbeahuruike, E E , Holm , Y, Vuorela, H , Amandikwa , C \& Fyhrquist, P 2019 , ' An ethnobotanical survey and antifungal activity of Piper guineense used for the treatment of fungal infections in West-African traditional medicine ' , Journal of Ethnopharmacology , vol. 229 , pp. 157-166 . https://doi.org/10.1016/j.jep.2018.10.005

http://hdl.handle.net/10138/327406

https://doi.org/10.1016/j.jep.2018.10.005

cc_by_nc_nd

acceptedVersion

Downloaded from Helda, University of Helsinki institutional repository.

This is an electronic reprint of the original article.

This reprint may differ from the original in pagination and typographic detail.

Please cite the original version. 
1 An ethnobotanical survey and antifungal activity of Piper guineense used for the 2 treatment of fungal infections in West-African traditional medicine

3 Eunice Ego Mgbeahuruike ${ }^{a}$, Yvonne Holm ${ }^{\mathrm{a}}$, Heikki Vuorela ${ }^{\mathrm{a}}$, Chinyere Amandikwa ${ }^{\mathrm{b}}$ and Pia 4 Fyhrquist $^{\mathrm{a}}$ ${ }^{a}$ Division of Pharmaceutical Biosciences, Faculty of Pharmacy, P.O. Box 56, FI-00014 University ${ }^{b}$ Department of Food Science and Technology, School of Engineering and Engineering Technology, 8 Federal University of Technology Owerri, P.M. B 1526, Owerri, Imo state, Nigeria. Yvonne.holm@helsinki.fi,Heikki.vuorela@helsinki.fi, Amandikwa125@yahoo.com,

*Corresponding author's e-mail: eunice.mgbeahuruike@helsinki.fi +358442399653

\section{Abstract}

Ethnobotanical relevance: Piper guineense occurs commonly in West Africa where it is used for fungal infections instead of the costly and not always accessible conventional antifungals. Fungal, yeast-based diseases are common in West-Africa especially among those living with HIV/ AIDS, and thus this study was performed in Imo state, South-Eastern Nigeria, where $P$. guineense is predominantly used for the treatment of fungal diseases, such as skin rashes, oral thrush and vaginosis. Aim of study: The scarce number of previous studies on the documentation of the traditional uses of $P$. guineense extracts for the treatment of fungal infections in Nigeria prompted this survey. The investigation focused on how traditional healers recognize and diagnose fungal infections, how $P$. guineense is collected, on the various parts used for the treatments, methods of preparations, administrations and treatments. In addition, an in vitro antifungal screening of $P$. guineense fruit and leaf extracts of various polarities, and piperine and piperlongumine, representing the main constituents in these extracts, were performed.

Methods: A house to house ethnobotanical survey was conducted using questionnaires. Twenty traditional medical practitioners (TMP) and herb sellers from ten villages were interviewed. Four human pathogenic strains of yeast and Cryptococcus neoformans, a yeast-like basidiomycete causing meningitis in immunocompromised individuals, were used for the antifungal screening. Results: The traditional medical practitioners (TMP) and herb sellers explained that the leaves and fruits are the most commonly used plant parts for the treatments. The oral intake of the extracts in locally produced bamboo alcohol (Kai-kai) is the most common method of administration. In 
accordance with these recorded traditional uses, we found that extracts of $P$. guineense were growth inhibitory against the fungal strains with MIC values ranging from 39 to $2500 \mu \mathrm{g} / \mathrm{mL}$. The lowest MIC value of $39 \mu \mathrm{g} / \mathrm{mL}$ was recorded for a methanol fruit extract against Candida albicans, $C$. glabrata and C. tropicalis. In addition, ethanol and hexane fruit extracts were effective against the growth of $C$. albicans and C. glabrata, respectively, with a MIC of $78 \mu \mathrm{g} / \mathrm{mL}$. Piperlongumine and piperine were active against $C$. albicans with MIC values of 39 and $78 \mu \mathrm{g} / \mathrm{mL}$ respectively. Conclusion: P. guineense fruit and leaf extracts, as well as their piperamide alkaloid constituents piperine and piperlongumine, have interesting antifungal properties and could have potential as new antifungal scaffolds. Our results warrant further in-depth investigations to isolate and characterize piperamide alkaloids and other compounds responsible for the antifungal activity in the extracts.

Key words: Piper guineense, antifungal uses, ethnobotanical survey, antifungal screening, piperine, piperlongumine

\section{Introduction}

Africa is richly endowed with medicinal plants that are utilized in the treatment of fungal diseases in traditional medicine and thus could be sources for standardized antifungal extracts and antifungal compounds. Examples of such plant species are Jatropha curcas L. (Euphorbiaceae), Monodora myristica Dunal. (Annonaceae), Xylopia aethiopica A. Rich. (Annonaceae) and Piper guineense Schumach \&Thonn (Piperaceae) (Ngane et al., 2003; Abdelgadir and Van Staden, 2013; Dzoyem and Kuete, 2013). The mortality rate associated with fungal diseases is high in Africa especially among those living with HIV/ AIDS (Park et al., 2009). Due to the high cost of conventional medicine and accessibility of numerous medicinal plants in Sub-Saharan Africa, $70-80 \%$ of the population use traditional medicine and plant-based preparations for the treatment of infectious diseases (Agyare et al., 2018). In most rural villages in Africa, the conventional health-care professionals are limited and there are no adequate health-care facilities, and thus, majority of the people patronize the traditional medical practitioners who use the readily available herbal formulations for the treatment of fungal infections (Osuchukwu et al., 2017). African guinea pepper (Piper guineense Schumach \&Thonn) is a medicinal plant and a spice that is highly valued in Africa because of its numerous ethno-medicinal uses (Besong et al., 2016; Ajibesin et al., 2011, Mgbeahuruike et al., 2017, 2018). The extracts of $P$. guineense are used to treat topical fungal diseases in West-African traditional medicine (Ngane et al., 2003). It is a vine that can grow up to $20 \mathrm{~m}$ in length with edible leaves and peppercorn fruits that have a strong pungent aroma 

2003). In another study, it was established that $P$. guineense extracts could be used as botanical fungicides by local farmers because of the high cost and toxicity associated with synthetic fungicides (Asawalam, 2006). According to previous research, herbal formulations from medicinal plants are often more effective and safer than those from isolated active compounds (Fabricant and Farnsworth, 2001), and thus standardized extracts could be used in the combat against fungal infections to minimize the risk of the development of resistance.

Table 1. Summary of ethno-medicinal uses, pharmacology/antifungal screening of Piper guineense.

\begin{tabular}{|c|c|c|c|}
\hline $\begin{array}{l}\text { P. guineense } \\
\text { plant part }\end{array}$ & $\begin{array}{l}\text { Ethno-medicinal uses with } \\
\text { reference source }\end{array}$ & $\begin{array}{l}\text { Pharmacology/ Antifungal activity } \\
\text { with reference source }\end{array}$ & In vivo/In vitro \\
\hline \multirow[t]{4}{*}{ Seeds/ Fruits } & $\begin{array}{l}\text { Seeds are used to prepare } \\
\text { decoctions for the treatment of } \\
\text { fungal infections (Ngane et al., } \\
\text { 2003). Seeds and fruits in } \\
\text { combination with other medicinal } \\
\text { plants such as Xylopia aethiopica } \\
\text { (Annonaceae) is boiled and } \\
\text { administered to nursing mothers to } \\
\text { aid the contraction of the uterus } \\
\text { (Okigbo and Igwe, 2007). }\end{array}$ & $\begin{array}{l}\text { Agar diffusion method with } 90 \% \\
\text { ethanolic extract and fractions } \\
\text { obtained by column chromatography. } \\
\text { Amphotericin B, Griseofulvin and } \\
\text { Clotrimazole at } 10 \mu \mathrm{g} / \mathrm{mL} \text { each were } \\
\text { used as positive controls. MIC } \\
\text { against Candida albicans, } \\
\text { Cryptococcus neoformans, } \\
\text { Scopulariopsis brevicaulis, } \\
\text { Aspergillus flavus, and Microsporum } \\
\text { gypseum were within the range of } 50 \\
-100 \mu \mathrm{g} / \mathrm{mL} \text { for the extracts (Ngane et } \\
\text { al., 2003). }\end{array}$ & $\begin{array}{l}\text { In vitro and in vivo (Ngane et } \\
\text { al., 2003). }\end{array}$ \\
\hline & $\begin{array}{l}\text { Seeds are used to prepare } \\
\text { decoctions for the treatment of } \\
\text { asthma and psychotic disorder } \\
\text { (Gbekley et al., 2017; Oyemitan et } \\
\text { al., 2015). The fruits are used for } \\
\text { respiratory infections, female } \\
\text { infertility, and aphrodisiac } \\
\text { (Dzoyem et al., 2014). Fruits are } \\
\text { used to prepare decoctions with } \\
\text { other herbs to treat epilepsy (Abila } \\
\text { et al. 1993). }\end{array}$ & $\begin{array}{l}\text { The fruits were extracted with a } \\
\text { mixture of methanol- } \\
\text { dichloromethane ( } 3: 1 \mathrm{~V} / \mathrm{V}) \text { for } 48 \mathrm{~h} \\
\text { at room temperature. Broth micro- } \\
\text { dilution method was used, Nystatin } \\
\text { was used as positive control, MIC } \\
\text { was between } 1.56 \text { to } 6.25 \mathrm{mg} / \mathrm{mL} \\
\text { against Candida albicans, Candida } \\
\text { parapsilosis, Candida tropicalis, } \\
\text { Candida krusei, Candida glabrata } \\
\text { and Cryptococcus neoformans } \\
\text { (Dzoyem et al., 2014) }\end{array}$ & In vitro (Dzoyem et al., 2014). \\
\hline & $\begin{array}{l}\text { Used for cough, bronchitis, } \\
\text { rheumatism and syphilis (Konning } \\
\text { et al., 2004; Sandberge et al., 2005). } \\
\text { The fruits are used to prepare Yaji } \\
\text { soup which is eaten as an } \\
\text { aphrodisiac in West African } \\
\text { countries (Ibrahim et al., 2010). }\end{array}$ & $\begin{array}{l}\text { Agar diffusion method, Soxhlet } 96 \% \\
\text { methanol extracts. Clotrimazole was } \\
\text { used as a positive control, inhibition } \\
\text { zones were between } 7.4 \text { to } 9.8 \mathrm{~mm} \\
\text { against Candida albicans and } \\
\text { Aspergillus niger (Konning et al., } \\
\text { 2004). }\end{array}$ & $\begin{array}{l}\text { In vitro (Konning et al., } \\
\text { 2004). }\end{array}$ \\
\hline & $\begin{array}{l}\text { It is mixed with other herbs to } \\
\text { produce Niprisan used in herbal } \\
\text { medicine in West Africa for the } \\
\text { treatment of sickle cell anemia } \\
\text { (Obodozie et al., 2010, Freiesleben } \\
\text { et al., 2015). }\end{array}$ & $\begin{array}{l}\text { Petroleum ether extract obtained by } \\
\text { Soxhlet extraction, aqueous extract } \\
\text { and } 95 \% \text { ethanolic extract. MIC was } \\
200 \mathrm{mg} / \mathrm{mL} \text { against Aspergillus niger, } \\
\text { No positive control was mentioned } \\
\text { (Ebana et al., 2016). }\end{array}$ & In vitro (Ebana et al., 2016). \\
\hline Leaves & Leaves have anticonvulsive & Petroleum ether extract obtained by & In vitro (Ebana et al., 2016). \\
\hline
\end{tabular}


activities and are used to make decoctions for the treatment of convulsion (Abila et al., 1993). Leaves are boiled with Xylopia aethiopica and taken for the treatment of malaria (Asase et al., 2012).

Leaves are used to prepare soup for the treatment of sexually transmitted diseases (Ajibesin et al., 2011).

Used for the treatment of dysentery and bronchitis (Ogunniran et al., 2009).

Root

No references found
Soxhlet extraction, aqueous extract and $95 \%$ ethanolic extract. MIC was $80 \mathrm{mg} / \mathrm{mL}$ against against Aspergillus niger, Significant antifungal activity was observed. No positive control was mentioned (Ebana et al., 2016).

Hexane and ethanol extracts. The diameter of the inhibition zones were

In vitro (Dada et al., 2013).

11.0-34.0 $\mathrm{mm}$ against Aspergillus niger and Aspergillus flavus (Dada et al., 2013).

Water extracts obtained by maceration. 5, 10 and $15 \%$ concentration of the water extract was used. The extracts were effective against Fusarium oxysporum at

higher concentrations of 10 and $15 \%$ (Abiala et al., 2015).

No references found

No references found
80

This present study is the first report resulting from an ethnobotanical survey on the traditional uses of $P$. guineense extracts for the treatment of fungal infections, including candidiasis, in SouthEastern Nigeria. Due to the frequent occurrence of fungal diseases in West Africa, this study was performed in Imo state, South-Eastern Nigeria, where $P$. guineense is predominantly used for the treatment of fungal diseases and for other various medicinal purposes. Imo state is one of the five states in South-Eastern Nigeria. The people in Imo state belong to the Igbo ethnic group and are predominantly Christians. This study area was selected because of the prevalence of fungal infections in the area, owing to the fact that it is a rain forest zone and the humid climate favours the occurrence of topical fungal infections. The area was also selected due to the fact that no previous investigations on the ethnopharmacology of $P$. guineense have been performed in this region.

Moreover, the area is inhabited by over 4.8 million people, who largely cultivate $P$. guineense and depend on this species and other medicinal plants for the treatment of infectious diseases and among them fungal infections. Also, the people have a diverse cultural and historical background, and are well grounded with the knowledge of traditional medicine. However, this valuable traditional medicinal knowledge is usually not documented. Thus, the aim of the study was to conduct an ethnobotanical survey in order to document the ways in which traditional healers and herb sellers utilize $P$. guineense extracts and preparations for the treatment of fungal diseases. The investigation was focused on how fungal infections are recognized and diagnosed, how and which parts of $P$. guineense are collected, methods of preparations, administrations and treatments. To validate the ethnobotanical information, an in vitro screening of $P$. guineese extracts of the fruit and leaf was performed against selected human pathogenic Candida spp. and Cryptococcus neoformans in search for new antifungal extracts and agents. 


\section{Materials and methods}

\subsection{Study area and survey}

107

108

Imo state is situated in South-Eastern Nigeria and share boundary with the South-South geopolitical zone of Nigeria. It is a tropical rain forest zone located between $4^{\circ} 45-7^{\circ} 15 \mathrm{~N}$ and $6^{\circ} 50$ $7^{\circ} 25 \mathrm{E}$, covering a total land area of $5,530 \mathrm{~km}^{2}$ (Fig. 1). An ethnobotanical survey was conducted in Imo state, where $P$. guineense is frequently used as herbal remedy in the treatment of candidiasis and other fungal diseases. The field work was conducted in ten localities between November and December 2017. A total of 20 traditional healers and herb sellers were interviewed (two from each locality). The purpose of the work was to validate the use of $P$. guineense in the treatment of fungal diseases. The 10 localities visited during the interviews were chosen by random sampling technique and are not clustered, but are all distributed within the three senatorial districts in Imo state as seen in Figure 1. The two traditional healers interviewed from each locality were independent from each other.

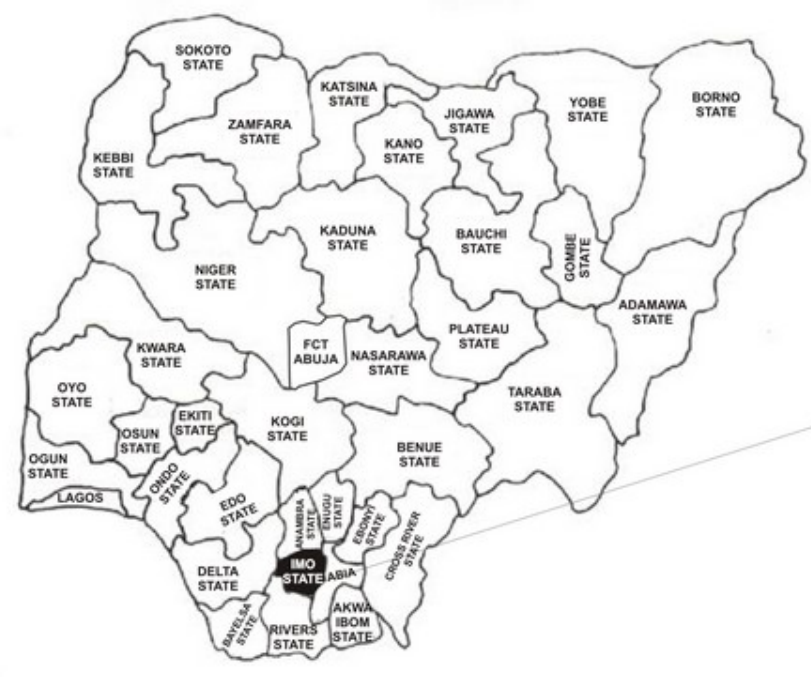

Map of Nigeria with Imo State shaded black

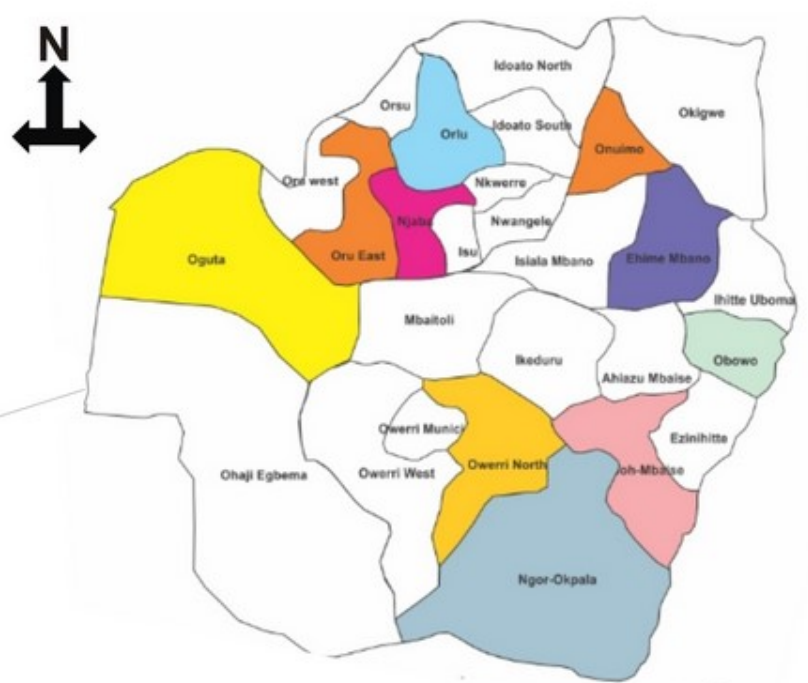

Map of Imo State showing the 10 localities with colours

Fig 1. Map of Nigeria showing the study area (Imo state) shaded in black and Map of Imo state showing the 10 localities shaded in colours. Source, Eunice Ego Mgbeahuruike, University of Helsinki, Finland and Chijioke Chukwueke (Graphic designer). 


\subsection{Data collection}

In the ethnobotanical survey, a house to house strategy was used with the permission of the village heads and traditional rulers. First, an ethical consideration of the project was done appropriately and approved by the University of Helsinki ethical committee, the survey plan was also approved by the head of the Division of Pharmaceutical Biosciences of the University of Helsinki, Finland. The village heads were notified prior to the investigation and the traditional healers were also well informed. The investigating team obtained an ethical approval from each of the village heads. The individual traditional healers gave an informed consent for the use of the data and pictures obtained during the interview. The consent was an oral agreement which was obtained from each of the traditional healers before the interviews began and permission to publish any photographs resulting from the interviews was obtained too. Detailed and validated questionnaires (Appendix A) were administered to twenty traditional healers ( 2 from each locality). This was followed by series of questions and conversations, so as to obtain the information needed for the work. The questionnaires were written in English, but the local language (Igbo) was used during the interviews and conversations because most of the participants could not interact well in English even though they had formal education. The traditional healers provided samples of the leaves, and fruits of $P$. guineense which was identified by a member of the investigating team who is a botanist. The traditional healers cooperated with our investigating team and some cash gifts were given to them at the end of the survey.

\subsection{Plant material for antifungal screening}

The fruits and leaves of $P$. guineense (African guinea pepper) used in this study were collected from a rural village in Imo State, South Eastern Nigeria. The plant materials were authenticated at the Department of Crop Science of the Federal University of Technology, Owerri, Nigeria. Voucher specimens are deposited in the herbarium of the Department of Crop Science of the same university with the specimen number FUTO/SAAT/NS/005A for the fruit and FUTO/SAAT/NS/005B for the leaf.

\subsection{Extraction}

The air dried plant materials were milled with a grinder to obtain finely ground powdery samples. Sequential extraction was carried out using solvents of varying polarities, starting with the least polar solvent. First, $40 \mathrm{~g}$ of the plant material was extracted with $300 \mathrm{~mL}$ of hexane, followed by extraction with $300 \mathrm{~mL}$ of chloroform, then $300 \mathrm{~mL}$ of ethanol and the residue was finally extracted and washed with $300 \mathrm{~mL}$ of methanol. Fruits and leaf plant materials were used for the extractions. 
The extraction with each of the solvents was conducted in duplicates and each extract, except from the water extracts, were filtered using filter paper (Whatman GE Healthcare, Chicago, IL, USA). The water extracts were centrifuged at $689 \mathrm{~g}$ for 5 minutes. For each extract, the filtrate was evaporated using a rotary evaporator (Rotavapor, Heidolph VV2000) combined with a water bath not exceeding $+40^{\circ} \mathrm{C}$, thereafter the extracts were lyophilized for two days to dry completely. Macerations and hot water decoctions were also prepared from the plant samples since these preparations are used in traditional medicine. Macerations were prepared by weighing $10 \mathrm{~g}$ of the fruits and leaf plant materials into Erlenmeyer flasks. $100 \mathrm{~mL}$ of water was added and extraction was performed for 24 hours using a magnetic stirrer. The mixture was centrifuged at $689 \mathrm{~g}$ for 15 min (Eppendorf AG centrifuge 5810R, Germany). For the decoctions, $10 \mathrm{~g}$ of the plant material was boiled with $100 \mathrm{~mL}$ of water and allowed to cool. The mixture was centrifuged for $15 \mathrm{~min}$ at $689 \mathrm{~g}$ (Eppendorf AG centrifuge 5810R, Germany). Both the macerations and decoctions were carefully filtered using filter paper (Schleicher \& Schuell, $\emptyset=150 \mathrm{~mm}$, Germany), and freeze dried for two days in a lyophilizer. Prior to the agar diffusion test, the freeze dried extracts were reconstituted and re-dissolved in their corresponding solvents or in $\mathrm{MeOH}$ to a final concentration of $50 \mathrm{mg} / \mathrm{mL}$ for the antifungal screening according to the method of Anyanwu and Nwosu, (2014) and Salih et al., (2017).

\subsection{Fungal strains}

The fungal strains used in this investigation were obtained from the Division of Pharmaceutical Biosciences, Faculty of Pharmacy, University of Helsinki, Finland. In all, the growth inhibitory activity of the extracts were investigated using five fungal strains (Candida albicans ATCC 10231, Candida glabrata ATCC 2001, Candida tropicalis ATCC 750, Candida parapsilosis ATCC 7330, and Cryptococcus neoformans ATCC 10226).

\subsection{Antibiotics and pure compounds}

Amphotericin-B (Sigma-Aldrich, St. Louis MO, USA) and itraconazole (Sigma-Aldrich, St. Louis MO, USA), were used as standard antibiotics for the investigation. Analytical grade piperine and piperlongumine standards ( $\geq 97.0 \%$ purity) purchased from TCI Europe N.V. (Zwijndrecht, Belgium) were used as standard compounds.

\subsubsection{Agar disk diffusion method}

Four human pathogenic strains of yeast and Cryptococcus neoformans, a yeast-like basidiomycete, were used to investigate the growth inhibitory effects of $P$. guineense extracts. A total of twelve 
extracts from the fruits and leaf extracts of this plant were tested against the fungi. An agar disk diffusion method was applied for the initial screening according to Salih et al., (2017). The freeze dried extracts were re-dissolved in those solvents used originally for their extraction according to the method of Anyanwu and Nwosu, (2014). Each of the extracts were prepared to a final concentration of $50 \mathrm{mg} / \mathrm{mL}$ (stock solution). Amphotericin-B and itraconazole were used as positive controls. The antibiotics were dissolved in methanol to a final concentration of $10 \mathrm{mg} / \mathrm{mL}$ used for the test. Sterile petri dishes ( $\varnothing=15 \mathrm{~cm}$, VWR Finland) were used for the screening. For the screening, twenty-five $\mathrm{mL}$ of sterile base agar (Antibiotic agar No. 2, Difco, VWR Finland) was applied as a bottom layer into the sterile petri dishes using a sterile, serological pipet (Falcon, Becton Labware Europe) and allowed to solidify. Thereafter twenty-five $\mathrm{mL}$ of Saboraud agar (OXOID, Thermo Fisher Scientific) was applied as the top layer. The petri dishes were all allowed to solidify, and then stored in $+4^{\circ} \mathrm{C}$. The screening started with inoculation of the fungal strains onto solid Saboraud agar slants which were incubated for $48 \mathrm{~h}$ at $+37^{\circ} \mathrm{C}$. The viable yeast cultures from the agar slants were used to prepare an inoculum for the test. Fungi from the agar slants were transferred into $2 \mathrm{~mL}$ of $0.9 \%(\mathrm{w} / \mathrm{v})$ sodium chloride $(\mathrm{NaCl})$ solution in a sterile glass tube using a sterile inoculation loop. $1 \mathrm{~mL}$ of the suspension was transferred into another sterile glass tube, and the absorbance was measured at $625 \mathrm{~nm}$ (UV-Visible Spectrophotometer, Pharmacia LKBBiochrom 4060). The other $1 \mathrm{~mL}$ of the suspension (sterile part) was diluted with the $0.9 \% \mathrm{NaCl}$ solution so that the absorbance at $625 \mathrm{~nm}$ becomes 0.1 (this suspension contains approximately 1.5 $\times 10^{8} \mathrm{CFU} / \mathrm{mL}$ ). $200 \mu \mathrm{L}$ of this diluted fungal suspension was spread evenly on each petri dish and left to dry for some seconds with the lid open. A sterile cork borer (11 mm diameter) was used to make six holes equidistantly from each other on the agar surface of the petri dishes. $200 \mu \mathrm{L}$ of the $50 \mathrm{mg} / \mathrm{mL}$ plant extracts and $200 \mu \mathrm{L}$ of the $10 \mathrm{mg} / \mathrm{mL}$ antibiotics were carefully pipetted into the holes respectively. Methanol, ethanol, hexane and chloroform, $200 \mu \mathrm{L}$ of each, were used as solvent controls respectively. The solvents were found not to inhibit the growth of the fungi. The petri dishes were incubated at $+4{ }^{\circ} \mathrm{C}$ for $1 \mathrm{~h}$, and thereafter they were incubated for $48 \mathrm{~h}$ at $+37^{\circ} \mathrm{C}$. The diameters of the zones of inhibition were measured with a caliper under a petri dish magnifier and expressed as the mean of the diameters of three replicates \pm SEM.

The Activity index (AI) of the various extracts were measured in relation to the standard antibiotics Amphotericin-B and itraconazole according to Fyhrquist et al., (2014).

Thus, AI = Inhibition zone of the plant extract Inhibition zone of standard antibiotic 


\subsubsection{Microdilution turbidimetric broth method for MIC and MFC estimation}

229 From the result obtained from the agar disk diffusion assay, minimum inhibitory concentration 230 (MIC) was estimated for some selected extracts based on their good antifungal activity. MIC is considered to be the lowest concentration of an extract or compound resulting in the inhibition of at least $90 \%$ of the growth of a fungal strain. MIC values were determined using a microdilution turbidimetric broth method based on the guidelines of Clinical and Laboratory Standards Institute (2012). Only extracts which expressed marked antifungal activity in the agar disk diffusion assay were tested for MIC. For the MIC evaluation, two-fold serial dilutions of the extracts from 9.75$2500 \mu \mathrm{g} / \mathrm{mL}$ were prepared in sterile Saboraud broth. Commercial pure compounds, piperine $(1 \mathrm{mg} / \mathrm{mL}$ concentration in methanol) and piperlongumine $(1 \mathrm{mg} / \mathrm{mL}$ concentration in methanol) were also two-fold serially diluted in Saboraud broth. Itraconazole and amphotericin-B were each two-fold serially diluted in Saboraud broth from $0.48-125 \mu \mathrm{g} / \mathrm{mL}$ respectively. 96 well microtiter plates were used for the tests (Nunc, Nunclone, Denmark). The fungal cultures were inoculated on Saboraud agar slants or in $5 \mathrm{~mL}$ Saboraud broth and grown for 48 hours at $+37^{\circ} \mathrm{C}$ before the test. The absorbance of $1 \mathrm{~mL}$ of the $48 \mathrm{~h}$ fungal culture was measured for turbidity at $\lambda=625 \mathrm{~nm}$ using a UV-Visible Spectrophotometer type 1510 (Thermo Fisher Scientific Oy). The absorbance was adjusted to 0.1 at $625 \mathrm{~nm}$ (approximately $1.0 \times 10^{8} \mathrm{CFU} / \mathrm{mL}$ ). $100 \mu \mathrm{L}$ of this suspension $\mathrm{A}_{625}=0.1$ was further diluted 100-fold to get a working suspension or inoculum containing $1.0 \times 10^{6}$ $\mathrm{CFU} / \mathrm{mL} .100 \mu \mathrm{L}$ of this inoculum, and $100 \mu \mathrm{L}$ of the plant extracts, pure compounds, antibiotics, and solvent controls, were pipetted into the 96 well microtiter plates. Therefore, each well contained $5 \times 10^{5} \mathrm{CFU} / \mathrm{mL}$. The solvent controls contained a maximum of $5 \%(\mathrm{v} / \mathrm{v})$ of each solvent to be tested for toxicity. At this concentration the solvents were found not to be toxic. The growth control (GC wells) contained only the fungal suspension, and the test wells ( $\mathrm{T}$ wells) contained plant extracts or pure compounds + fungal suspension. Moreover, sample controls wells were prepared for each plant extract/compound to be tested, and these wells contained plant extract/pure compound and the broth only. The microwell plates were incubated for 48 hours in an incubator coupled to a shaker at $+37^{\circ} \mathrm{C}$. The turbidity of the wells at $\lambda=620 \mathrm{~nm}$ was recorded using a Victor 1420 spectrophotometer (Wallac, Finland). The tests were done in triplicate and the \% growth was expressed as the mean of these triplicates \pm standard error of mean (SEM). The minimum fungicidal concentration (MFC) was evaluated by pipetting $100 \mu \mathrm{L}$ from those wells of the microtiter plate, which contained the MIC concentration as well as 2 and 4 times higher concentrations than their MIC values on petri dishes $(\varnothing=9 \mathrm{~cm})$ containing Saboraud agar, and incubating the dishes for 48 
hours at $+37^{\circ} \mathrm{C}$. The MFC was taken as the lowest concentration where no visible growth on the petri dish was observed after the incubation.

\section{Results and discussion}

\subsection{Ethnobotanical survey and field study}

An ethnobotanical survey was carried out in Imo state in South-Eastern Nigeria, as shown in Fig. 1. During the interviews and conversations, the various methods of preparations and administrations of the decoctions and concoctions from the roots, leaves, and fruits of $P$. guineense for the treatment of fungal diseases, were widely explained by the traditional healers. 20 traditional healers (14 male and 6 female) were interviewed with the cooperation of their village heads. The participants were between the ages of 40 to 70 years. In the communities visited, it was observed that most of the traditional healers are of older age and have long been practicing traditional medicine. It was also observed that there were more male than female traditional healers and this is in line with previous findings that there are more male than female traditional healers in Africa (Cheikhyoussef, et al., 2011; Ngarivhume et al., 2015). The socio-economic characteristics of the respondents are shown in Table 2.

Table 2. Demographic characteristics of the respondents $(n=20)$

\begin{tabular}{lll}
\hline Parameters & Specifications & Number of Respondents \\
\hline Gender & Male & 14 \\
Occupation & Female & 6 \\
& Herbalist & 7 \\
Age & Traditional medical practitioners & 5 \\
& Traditional healers/ herb sellers & 8 \\
& $20-35$ & 0 \\
Year of practice (experience) & $36-55$ & 9 \\
& $56-75$ & 11 \\
Learning/source of knowledge of & $1-15$ years & 6 \\
traditional medicine & $16-30$ years & 9 \\
\multirow{2}{*}{ Level of Education } & 31 years and above & 5 \\
& Inherited and learnt from parents & 12 \\
& & \\
& Training from other herbalists & 8 \\
Religion & University education & 3 \\
& High school & 8 \\
& Primary education & 6 \\
& No formal education & 3 \\
& Christianity & 16 \\
& Traditionalist & 4 \\
& Islam & 0 \\
\hline
\end{tabular}

279 Interestingly, most of the traditional healers have remarkable experience in traditional medicine and 280 have inherited and learnt the practice from their parents. All the participants have practiced herbal 
medicine for a long period of time, and 11 out of the 20 participants have practiced traditional medicine for over 25 years as their only source of income. Notably, some of the participants also had university education and thus some of the information on the preparation of $P$. guineense they also had in written form. One of the traditional healers has a big herbal clinic where he displayed various herbal preparations from $P$. guineense and he is referred to as "Doctor" in his community. It was observed during the course of this study that most of the traditional healers could read and write, that is to say that the trend in traditional medicine in Africa is gradually changing to become a modern profession. It was also observed that some of the traditional healers have books where they recorded the name of each patient and the treatments. From the survey, a variety of herbal preparations from various parts of $P$. guineense were identified. The respondents explained the sources from which they obtain the plant materials for their traditional healing practice. Most of them, apart from traditional healing practice, are also farmers. They have farms within their yards where they planted $P$. guineense and other medicinal plants to be used for the treatment of various infectious diseases and for the purpose of making local profit. The participants explained that they sometimes sell $P$. guineense fruits and leaves in local markets as spices and medicine to the general population. This illustrates that the traditional healers do not have problems in getting the plant materials used for the herbal treatments since they are sold in the local markets. All the respondents gave similar explanations on the symptoms and methods of diagnosis of the fungal infections. The traditional healers explained that they could differentiate between bacterial, viral and fungal infections based on the symptoms they observe in their patients especially when it comes from fungal skin infection and oral thrush. They argued that it was easy for them to identify and differentiate between these infections owing to their long time practice of traditional medicine. They gave some common symptoms for the various fungal infections as shown in Table 3 . The method of preparation ranges from hot infusion, decoction in combination with Xylopia aethiopica and then the plant material is soaked in mild alcohol as shown Table 3.

The traditional healers understood the dangers of fungal infections and sometimes send their patients to the government hospitals if the symptoms persist as a result of their failed treatment or lack of proper understanding of the type of fungal infection. The participants explained widely the methods of administration of $P$. guineense extracts. The oral intake is the most common method of administration and these correlates with the findings of Maroyi, (2013) that herbal preparations are mostly administered orally by traditional healers. The traditional healers argued that the decoctions made from the fruits and leaves, prepared in mild alcohol is mostly effective when administered orally for the treatment of fungal diseases expressed by thrush on the tongue or candidal vaginosis. 
When asked about the dosage, they further explained that it is usually taken with a small glass tumbler which can be measured to be about $100 \mathrm{~mL}, 3$ to 4 times in a day. It was observed that the leaves and fruits are the most frequently used plant parts for the treatments and this correlates with the findings of Rahmatullah et al., (2012), that the leaves of medicinal plants are used more often in traditional medicine than the other plant parts perhaps because leaves are easy to collect. The traditional healers cooperated with the investigating team and claimed that their methods were effective in the treatment of fungal infections. This study demonstrates that the traditional healers could easily identify $P$. guineense owing to their long practice of the use of extracts of this species in herbal medicine. Our results indicate that $P$. guineense is an important medicinal plant which is highly utilized in the treatment of fungal infections in Imo state, South- Eastern Nigeria and could be a source for the discovery of a new antifungal scaffolds for drug discovery.

Table 3. List of fungal diseases often treated with $P$. guineense herbal remedies in Imo state, South 328 Eastern Nigeria and the symptoms used by the traditional healers to diagnose the fungal infections. Frequency means the number of healers that mentioned it.

\begin{tabular}{|c|c|c|c|c|c|c|}
\hline Diseases & $\begin{array}{l}\text { Local names } \\
\text { in native Igbo } \\
\text { language }\end{array}$ & $\begin{array}{l}\text { Symptoms/ } \\
\text { Method of } \\
\text { diagnosis }\end{array}$ & Plant parts used & $\begin{array}{l}\text { Method of } \\
\text { preparation }\end{array}$ & Administration & Frequency \\
\hline Skin ringworm & $\begin{array}{l}\text { Nwanra, ọria } \\
\text { ringoringo }\end{array}$ & $\begin{array}{l}\text { Ring-like } \\
\text { rashes, and } \\
\text { fever }\end{array}$ & $\begin{array}{l}\text { Fruits and } \\
\text { leaves }\end{array}$ & $\begin{array}{l}\text { Soaked in } \\
\text { alcohol local } \\
\text { gin (Kai-kai) }\end{array}$ & Taken orally & 8 \\
\hline $\begin{array}{l}\text { Vaginal } \\
\text { candidiasis }\end{array}$ & Oria nwanyi & $\begin{array}{l}\text { Vagina itching, } \\
\text { unpleasant } \\
\text { vaginal } \\
\text { discharge, fever }\end{array}$ & $\begin{array}{l}\text { Leaves, fruits, } \\
\text { roots }\end{array}$ & $\begin{array}{l}\text { Soaked in } \\
\text { alcohol local } \\
\text { gin (Kai-kai) }\end{array}$ & $\begin{array}{l}\text { Administered } \\
\text { orally }\end{array}$ & 6 \\
\hline $\begin{array}{l}\text { Fungal eye } \\
\text { infection }\end{array}$ & Ọia anya & $\begin{array}{l}\text { Eye itching, } \\
\text { swollen of the } \\
\text { eye }\end{array}$ & Leaves & $\begin{array}{l}\text { Cold and hot } \\
\text { water infusion }\end{array}$ & $\begin{array}{l}\text { Administered } \\
\text { in drops in the } \\
\text { eye }\end{array}$ & 3 \\
\hline Skin diseases & Oria enuahụ & $\begin{array}{l}\text { Rashes, itching, } \\
\text { reddish skin, } \\
\text { blisters }\end{array}$ & $\begin{array}{l}\text { Fruits and } \\
\text { leaves }\end{array}$ & $\begin{array}{l}\text { Cold } \\
\text { maceration } \\
\text { combined with } \\
\text { Zingiber } \\
\text { officinale }\end{array}$ & $\begin{array}{l}\text { Applied on the } \\
\text { skin }\end{array}$ & 8 \\
\hline $\begin{array}{l}\text { Urinary } \\
\text { infections }\end{array}$ & Ọria akpaamịrị & $\begin{array}{l}\text { Painful } \\
\text { urination, } \\
\text { constant } \\
\text { stooling and } \\
\text { body weakness }\end{array}$ & $\begin{array}{l}\text { Leaves, and } \\
\text { fruits }\end{array}$ & $\begin{array}{l}\text { Soaked in } \\
\text { alcohol local } \\
\text { gin (Kai-kai) }\end{array}$ & $\begin{array}{l}\text { Administered } \\
\text { orally }\end{array}$ & 5 \\
\hline $\begin{array}{l}\text { Mouth } \\
\text { infections/ } \\
\text { Thrush }\end{array}$ & $\begin{array}{l}\text { Ọbu, Ọria } \\
\text { Ọnuụ, } \\
\text { nla }\end{array}$ & $\begin{array}{l}\text { Blisters in the } \\
\text { mouth, sour } \\
\text { throat, and } \\
\text { fever }\end{array}$ & $\begin{array}{l}\text { Fruits and } \\
\text { leaves }\end{array}$ & $\begin{array}{l}\text { Decoction } \\
\text { combined with } \\
\text { Xylopia } \\
\text { aethiopica }\end{array}$ & $\begin{array}{l}\text { Used to wash } \\
\text { the mouth } \\
\text { regularly and } \\
\text { taken orally }\end{array}$ & 7 \\
\hline $\begin{array}{l}\text { Nail infections/ } \\
\text { athlete's foot }\end{array}$ & Ogbaukwu & $\begin{array}{l}\text { Reddish and } \\
\text { swollen toes } \\
\text { and nails, itchy } \\
\text { small blisters }\end{array}$ & $\begin{array}{l}\text { Leaves, and } \\
\text { fruits }\end{array}$ & $\begin{array}{l}\text { Soaked in mild } \\
\text { alcohol local } \\
\text { gin (Kai-kai) }\end{array}$ & Taken orally & 8 \\
\hline Scalp ringworm & $\begin{array}{l}\text { Ọria } \\
\text { Isiakpụkpọ, } \\
\text { Akpụkpọisi }\end{array}$ & $\begin{array}{l}\text { Bald patches, } \\
\text { rashes and } \\
\text { painful blisters } \\
\text { on the head, } \\
\text { fever and } \\
\text { headache }\end{array}$ & $\begin{array}{l}\text { Fruits and } \\
\text { leaves }\end{array}$ & $\begin{array}{l}\text { Soaked in mild } \\
\text { alcohol to } \\
\text { produce a } \\
\text { paste, Hot } \\
\text { infusion }\end{array}$ & $\begin{array}{l}\text { Applied as } \\
\text { paste on the } \\
\text { affected area, } \\
\text { infusion taken } \\
\text { orally }\end{array}$ & 8 \\
\hline
\end{tabular}


The leaf and fruit extracts of $P$. guineense were most frequently used for skin diseases, nail infections/ athlete's foot, scalp ringworm and skin ringworm (recorded 8 times by the 20 traditional healers). Mouth infections/ Thrush and vaginal candidiasis were recorded 7 and 6 times respectively.

From previous reports, $P$. guineense extracts of the seed, fruit and leaf contained piperamide compounds such as piperine, dihydropiperine, piperylin, piperlonguminine, dihydropiperlonguminine, wisanine and dihydrowisanine (Adesina et al, 2003; Scott et al., 2005). However, to the best of our knowledge, no reports are available on the antifungal effects of isolated phytochemicals from $P$. guineense. The chemical structures of piperine, 4, 5-dihydropiperine, piperlonguminine, 4, 5-dihydropiperlonguminine, and piperylin are shown in Figure 2. These bioactive compounds have been identified as the major bioactive compounds in $P$. guineense fruit extract (Scott et al., 2005).<smiles>O=C(/C=C/C=C/c1ccc2c(c1)OCO2)N1CCCCC1</smiles>

1 Piperine<smiles>CC(C)CNC(=O)/C=C/CCc1ccc2c(c1)OCO2</smiles>

3 Piperlonguminine<smiles>CCCCCCCCCCCC(=O)N1CCCC1</smiles><smiles>O=C(C/C=C/Cc1ccc2c(c1)OCO2)N1CCCCC1</smiles>

2 4,5-dihydropiperine<smiles>CC(C)CNC(=O)/C=C/C=C/c1ccc2c(c1)OCO2</smiles>

4 4, 5-dihydropiperlonguminine

Fig. 2. Chemical structures of some piperamide compounds in Piper guineense fruits

\subsection{Antifungal activity}

In the present study, a total of 12 extracts of various polarities from the leaf and fruit of $P$. guineense, as well as hot water decoctions and cold water macerations were screened for antifungal activity against four yeast strains and C. neoformans (Table 4 and 5). Additionally, piperine and piperlongumine commercial piperamide compounds were also screened for antifungal activity. The screening was done based on our ethnobotanical results on the uses of $P$. guineense in West-African 
traditional medicine for the treatment of fungal diseases (Table 3). For the investigation, some potentially pathogenic fungal strains of Candida spp. and Cryptococcus neoforamns, which could be responsible for some of the fungal diseases treated by the traditional healers were chosen. Among all the fungal strains selected, $C$. albicans is known to be the most significant human pathogenic species of yeast that can cause serious fungal diseases in humans (Brown et al., 2014). The extracts were found to exhibit marked antifungal activity against the various fungi used in our study and MIC values, as low as $39 \mu \mathrm{g} / \mathrm{mL}$ were recorded against some of the fungal strains (Table 5). Our results are in agreement with a previous report that fractions, natural compounds and extracts from $P$. guineense can be explored as antifungal agents in the prevention of skin infection (Ngane et al., 2003). Moreover, evaluation of the antifungal potentials of $P$. guineense extracts along with other Cameroonian spices, revealed that the fruit extract of $P$. guineense is effective against $C$. albicans, $C$. parapsilosis, $C$. tropicalis, $C$. neoformans, and $C$. glabrata with MIC values ranging from 1560-6250 $\mu \mathrm{g} / \mathrm{mL}$ (Dzoyem et al., 2014). Compared to this study, we recorded even lower MIC and MFC values which could be due to different kinds of extraction methods, Dzoyem et al. (2014) using only methanol: dichloromethane (3:1), but not sequential extraction. Generally, from our study, we observed that the leaf extracts showed a different spectrum of activity compared to the fruits. For example, the hexane leaf extract showed an inhibition zone of $21.7 \mathrm{~mm}$ against $C$. albicans, whereas the hexane fruit extract only gave an IZ of $14.3 \mathrm{~mm}$ against this fungus. The result correlated well with the MIC values, which were recorded to be $78 \mu \mathrm{g} / \mathrm{mL}$ for the leaf extract and $625 \mu \mathrm{g} / \mathrm{mL}$ for the fruit extract (Table 5). A similar trend was observed with the leaf extract in ethanol which gave an inhibition zone of $23.8 \mathrm{~mm}$, whereas the fruit extract gave an IZ of $22.2 \mathrm{~mm}$ against Cryptococcus neoformans. The MIC values were $78 \mu \mathrm{g} / \mathrm{mL}$ and 156 $\mu \mathrm{g} / \mathrm{mL}$, respectively. However, this could be attributed to the fact that the concentration of the antifungal compounds varies between different extracts, thus, this result demonstrates that the leaves might contain a larger quantity of the bioactive compounds responsible for the antifungal activity compared to the fruit extracts. This result could be supported by our ethnobotanical survey results, where the traditional healers explained that the leaves of $P$. guineense are sometimes more active in the treatment of some of the fungal infections and are therefore used more frequently than the fruit for some specific symptoms of fungal infection. Moreover, our results are in accordance with Rahmatullah et al., (2012), who argued that the leaf extracts of medicinal plants are used more often in traditional medicine because they are usually more effective than extracts made from other plant parts. 
Table 4. Antifungal effects of extracts of $P$. guineense, piperine and piperlongumine against four potentially pathogenic strains of yeast and Cryptococcus neoformans. Results obtained with the agar diffusion method.

\begin{tabular}{|c|c|c|c|c|c|}
\hline $\begin{array}{l}\text { Plant extracts and } \\
\text { antibiotics }\end{array}$ & $\begin{array}{l}\text { Candida } \\
\text { glabrata }\end{array}$ & $\begin{array}{l}\text { Candidaal } \\
\text { bicans }\end{array}$ & $\begin{array}{l}\text { Candida } \\
\text { parapsilosis }\end{array}$ & $\begin{array}{l}\text { Candida } \\
\text { tropicalis }\end{array}$ & $\begin{array}{l}\text { Cryptococcus } \\
\text { neoformans }\end{array}$ \\
\hline PSMeOH & $\mathbf{2 4 . 3} \pm 0,33$ & $\mathbf{2 0 , 3} \pm 0,33$ & $18,0 \pm 0,33$ & $\mathbf{2 1 , 3} \pm 0,67$ & $\mathbf{1 9 , 7} \pm 0,33$ \\
\hline AI. Itra. & 1,49 & 0,80 & 0,61 & 0,82 & 0,66 \\
\hline AI. Amp. & 0,71 & 0,57 & 0,41 & 0,73 & 0,52 \\
\hline $\mathrm{PSCHCL}_{3}$ & $\mathbf{2 3}, \mathbf{3} \pm 0,33$ & $17,7 \pm 0,33$ & $14,7 \pm 0,67$ & $16,2 \pm .0,17$ & $18,2 \pm 0,17$ \\
\hline AI. Itra. & 1,43 & 0,70 & 0,49 & 0,62 & 0,61 \\
\hline AI. Amp. & 0,68 & 0,50 & 0,34 & 0,55 & 0,48 \\
\hline PSHex & $\mathbf{2 0 , 3} \pm 0,33$ & $14,3 \pm 0,33$ & $15,3 \pm 0,67$ & $11,0 \pm 0,58$ & $14,3 \pm 0,33$ \\
\hline AI. Itra. & 1,24 & 0,57 & 0,52 & 0,42 & 0,48 \\
\hline AI. Amp. & 0,59 & 0,40 & 0,35 & 0,38 & 0,38 \\
\hline $\mathrm{PSH}_{2} \mathrm{O}^{*}$ & NA & NA & NA & NA & NA \\
\hline $\mathrm{PSHH}_{2} \mathrm{O}$ & NA & NA & NA & NA & NA \\
\hline PSEthanol & NT & $\mathbf{2 1 , 8} \pm 0,17$ & NT & $\mathbf{1 9 , 8} \pm 0,17$ & $\mathbf{2 2}, \mathbf{2} \pm 0,17$ \\
\hline AI. Itra. & NT & 0,86 & NT & 0,76 & 0,75 \\
\hline AI. Amp. & NT & 0,61 & NT & 0,68 & 0,58 \\
\hline PLMeOH & $\mathbf{2 0 , 7} \pm 0,31$ & $\mathbf{1 9 , 7} \pm 0,33$ & $\mathbf{2 8}, 7 \pm 0,67$ & $17,3 \pm 0,33$ & $\mathbf{2 1 , 3} \pm 0,67$ \\
\hline AI. Itra. & 1,27 & 0,78 & 0,97 & 0,66 & 0,72 \\
\hline AI. Amp. & 0,60 & 0,55 & 0,66 & 0,59 & 0,56 \\
\hline $\mathrm{PLCHCL}_{3}$ & $11,7 \pm 0,33$ & $18,0 \pm 0,00$ & $13,7 \pm .0,17$ & $15,5 \pm 0,50$ & $17,3 \pm 0,33$ \\
\hline AI. Itra. & 0,71 & 0,71 & 0,46 & 0,59 & 0,58 \\
\hline AI. Amp. & 0,34 & 0,50 & 0,31 & 0,53 & 0,46 \\
\hline PLHex & $13,7 \pm 0,33$ & $\mathbf{2 1 , 7 \pm 0 , 3 3}$ & $17,8 \pm 0,17$ & $12,0 \pm 0,58$ & $11,7 \pm 0,33$ \\
\hline AI. Itra. & 0,84 & 0,86 & 0,60 & 0,46 & 0,39 \\
\hline AI. Amp. & NT & 0,61 & 0,41 & 0,41 & 0,31 \\
\hline $\mathrm{PLH}_{2} \mathrm{O}^{*}$ & NA & NA & NA & NA & NA \\
\hline $\mathrm{PLHH}_{2} \mathrm{O}$ & NA & NA & NA & NA & NA \\
\hline PLEthanol & NT & $\mathbf{1 9 , 8} \pm 0,17$ & NT & $18,2 \pm 0,17$ & $\mathbf{2 3 , 8} \pm 0,17$ \\
\hline AI. Itra. & NT & 0,78 & NT & 0,69 & 0,80 \\
\hline AI. Amp & NT & 0,56 & NT & 0,62 & 0,63 \\
\hline \multicolumn{6}{|l|}{ Pure compounds } \\
\hline Piperine & $17,3 \pm 0,67$ & $18,3 \pm .0,33$ & $\mathbf{2 3}, \mathbf{3} \pm 0,33$ & $16,7 \pm 0,67$ & $11,0 \pm .0,00$ \\
\hline AI. Itra. & 1,06 & 0,72 & 0,79 & 0,64 & 0,37 \\
\hline AI. Amp & 0,50 & 0,51 & 0,53 & 0,57 & 0,29 \\
\hline Piperlongumine & $14,7 \pm 0,33$ & $\mathbf{1 9 , 3} \pm .0,33$ & $16,3 \pm 0,33$ & $18,0 \pm 0,00$ & $11,8 \pm 0,17$ \\
\hline AI. Itra. & 0,90 & 0,76 & 0,55 & 0,69 & 0,40 \\
\hline AI. Amp & 0,43 & 0,54 & 0,37 & 0,61 & 0,31 \\
\hline \multicolumn{6}{|l|}{ Antifungal drugs } \\
\hline Itraconazole & $16,3 \pm 0,33$ & $\mathbf{2 5 , 3} \pm .0,33$ & $\mathbf{2 9 , 7} \pm 0,67$ & $\mathbf{2 6}, \mathbf{2} \pm 0,17$ & $\mathbf{2 9 , 7} \pm 0,33$ \\
\hline AI. Amp & 0,48 & 0,71 & 0,68 & 0,89 & 0,78 \\
\hline Amphotericin B & $\mathbf{3 4 , 3} \pm 0,33$ & $\mathbf{3 5 , 7} \pm 0,33$ & $\mathbf{4 3 , 7} \pm 0,67$ & $\mathbf{2 9 , 3} \pm .0,67$ & $\mathbf{3 8 , 0} \pm 0,00$ \\
\hline AI. Itra. & 2,10 & 1,41 & 1,47 & 1,12 & 1,28 \\
\hline \multicolumn{6}{|l|}{ Solvent controls } \\
\hline Methanol & 2.3 & 2,8 & NA & NA & NA \\
\hline Chloroform & NA & NA & NA & NA & NA \\
\hline Hexane & 3,8 & 2,3 & NA & NA & NA \\
\hline Ethanol & NT & 3,7 & NT & 2,3 & NA \\
\hline
\end{tabular}
and fractions $(50 \mathrm{mg} / \mathrm{mL})$, as well as pure compounds and antibiotics $(10 \mathrm{mg} / \mathrm{mL})$ were applied in the wells. PSMeOH, P. guineense fruit methanol extract; $\mathrm{PSCHCL}_{3}, P$. guineense fruit chloroform extract; $\mathrm{PSHex}, P$. guineense fruit hexane extract; $\mathrm{PSH}_{2} \mathrm{O}^{*}, P$. guineense fruit cold water maceration; $\mathrm{PSHH}_{2} \mathrm{O}, P$. guineense fruit hot water decoction; PSEthanol, P. guineense fruit ethanol extract; PLMeOH, $P$. guineense leaf methanol extract; PLCHCL $_{3}, P$. guineense leaf chloroform extract; PLHex, $P$. guineense leaf hexane extract; $\mathrm{PLH}_{2} \mathrm{O}^{*}, P$. guineense leaf cold water maceration; $\mathrm{PLHH}_{2} \mathrm{O}, P$. guineense leaf hot water decoction; PLEthanol, $P$. 
guineense leaf ethanol extract; AI Itra., activity index in relation to itraconazole; AI Amp., activity index in relation to amphotericin B; NA, not active and NT, not tested. The results marked with bold show promising antifungal activity.

Interestingly, the water extracts were not active against the fungal strains evaluated in our study. Our results are consistent with a previous report that cold water macerations and hot water decoctions of $P$. guineense are not active against $C$. albicans and other Candida spp. (Okigbo and Igwe, 2007). Contrary to our results, water extracts of $P$. guineense are used in traditional medicine for fungal infections, even though it is sometimes administered as herbal formulations in combination with other medicinal plants, and often mixed with the local gin (Table 3). In our study, we observed that some of the alcohol and n-hexane extracts have marked antifungal activity with MIC values as low as $39 \mu \mathrm{g} / \mathrm{mL}$, and the inhibitory activity recorded with these extracts could result from their piperamide compounds, which are not well dissolved in water. It is possible that the water extracts contain only small quantities of piperamide alkaloids, which might explain their inactivity against the yeasts. The water extracts may contain other bioactive compounds than alkaloids, and thus $P$. guineense water extracts might be better to use in combination with other medicinal plants as herbal remedy for treatment of fungal infections in traditional medicine, which could explain the uses of $P$. guineense water extracts as concoctions for fungal infections in WestAfrican traditional medicine.

Our results demonstrate that the ethanol fruit and leaf extracts of $P$. guineense give good growth inhibition against C. albicans (IZ $21.8 \mathrm{~mm}$ and $19.8 \mathrm{~mm}$, respectively) (Table 4), and accordingly both extracts gave low MIC values of $78 \mu \mathrm{g} / \mathrm{mL}$ against $C$. albicans. C. albicans is an opportunistic pathogenic fungus that can cause serious systemic infections in humans, affecting mostly individuals with compromised immune defences, such as HIV/AIDS patients and elderly people (Brown et al., 2014). C. albicans is the main causative agent of candidiasis and our results are in agreement with the traditional uses of the fruits and leaves soaked in mild alcohol for the treatment of vaginal candidiasis (Table 3). Our result is also consistent with a previous report by Ejele et al., (2012), that ethanol extracts of $P$. guineense have significant activity against $C$. albicans. We also observed significant and promising growth inhibitory results of $20.3 \mathrm{~mm}$ and $19.7 \mathrm{~mm}$ with the methanol fruit and leaf extracts against $C$. albicans. Moreover, the chloroform extracts were active against $C$. albicans with a MIC value of $78 \mu \mathrm{g} / \mathrm{mL}$ for the leaf and fruit extracts. In our screenings, piperlongumine was found to be very active against $C$. albicans with a MIC value of $39 \mu \mathrm{g} / \mathrm{mL}$, while piperine gave a MIC of $78 \mu \mathrm{g} / \mathrm{mL}$. To the best of our knowledge, the inhibitory efficacy of piperlongumine has not been tested against C. albicans, and little information is available on the activity of piperine on Candida species. Since there is a report of multi-drug resistance in $C$. albicans (Gulshan and Moye-Rowley, (2007), our result demonstrates that piperlongumine and 
piperine could be scaffolds for new natural plant derived antifungal agents to combat multi-drug resistance in Candida strains. More research should be conducted to ascertain the antifungal mechanism of action of piperamide alkaloids as well as on producing extracts of $P$. guineense leaves or fruits which would be standardized to their piperamide alkaloid contents.

In comparison to our results with the plant extracts and alkaloids, our amphotericin-B standard drug showed a large inhibitory zone of $35.7 \mathrm{~mm}$ and a MIC of $0.48 \mu \mathrm{g} / \mathrm{mL}$ against $C$. albicans. The activity of $P$. guineense extracts and its piperamide alkaloids on $C$. albicans demonstrates that its extracts and alkaloids could be effectively utilized in combinations with conventional antifungals for the treatment of infections caused by antibiotic resistant $C$. albicans strains.

We also recorded promising growth inhibitory effects against C. glabrata, the second most significant human pathogenic species of yeast.The methanol, chloroform, and hexane extracts were all more active against $C$. glabrata than itraconazole (Table 4). Methanol and chloroform extracts gave the largest inhibition zones against C. glabrata (IZ ranging from $24.3 \mathrm{~mm}$ to $20.7 \mathrm{~mm}$ ) (Table 4). The MIC value for the chloroform fruit extract was $78 \mu \mathrm{g} / \mathrm{mL}$. Notably, itraconazole was only moderately active against $C$. glabrata, with an inhibition zone of $16.3 \mathrm{~mm}$ and a MIC value of 15.6 $\mu \mathrm{g} / \mathrm{mL}$. Drug-resistance against itraconazole has been found to be associated with $5 \%$ of nosocomial isolates of C. glabrata (Walker et al., 2013), and our results demonstrate that extracts of $P$. guineense could be sources for new antifungal scaffolds and drug adjuvants against drug resistant C. glabrata. A very low MIC value of $0.48 \mu \mathrm{g} / \mathrm{mL}$ was recorded with amphotericin B against $C$. glabrata, and our result is in agreement with the more frequent use of amphotericin B for the treatment of severe infections caused by $C$. glabrata (Mario et al., 2012). Piperine was active against $C$. glabrata with a MIC of $78 \mu \mathrm{g} / \mathrm{mL}$, while piperlongumine was moderately active with a MIC value of $156 \mu \mathrm{g} / \mathrm{mL}$. Apart from C. albicans, C. glabrata is another important fungal pathogen responsible for systemic infections which are associated with high mortality rate (Pfaller et al., $2004 ; 2007)$. Our results demonstrate that the extracts and the piperamide compounds could be possible sources and antifungal drug scaffolds for the discovery of a new antifungal drugs and drug adjuvants for the treatment of systemic infections caused by $C$. glabrata.

Table 5. Minimum inhibitory concentration and minimum fungicidal concentrations (MIC and $\mathrm{MFC}$ ) in $\mu \mathrm{g} / \mathrm{mL}$ of fruit and leaf extracts of Piper guineense and the alkaloids piperine and piperlongumine 


\begin{tabular}{|c|c|c|c|c|c|}
\hline \multicolumn{6}{|c|}{ PSMeOH } \\
\hline MIC & 39 & 39 & 625 & 39 & 156 \\
\hline MFC & 78 & 78 & 1250 & 78 & 312 \\
\hline \multicolumn{6}{|c|}{$\mathrm{PSCHCL}_{3}$} \\
\hline MIC & 78 & 78 & 625 & 312 & 156 \\
\hline $\mathrm{MFC}$ & 312 & 156 & 125 & 625 & 312 \\
\hline \multicolumn{6}{|l|}{ PSHex } \\
\hline MIC & 78 & 625 & 625 & 625 & 1250 \\
\hline MFC & 1250 & 1250 & 1250 & 1250 & 2500 \\
\hline \multicolumn{6}{|c|}{ PSEthanol } \\
\hline MIC & NT & 78 & NT & 78 & 156 \\
\hline MFC & NT & 156 & NT & 156 & 625 \\
\hline \multicolumn{6}{|c|}{ PLMeOH } \\
\hline MIC & 78 & 156 & 312 & 78 & 156 \\
\hline MFC & 156 & 312 & 625 & 156 & 312 \\
\hline \multicolumn{6}{|c|}{$\mathrm{PLCHC}_{3}$} \\
\hline MIC & 78 & 78 & 625 & 312 & 156 \\
\hline MFC & 156 & 156 & 1250 & 625 & 312 \\
\hline \multicolumn{6}{|l|}{ PLHex } \\
\hline MIC & 312 & 78 & 625 & 312 & 1250 \\
\hline MFC & 625 & 625 & 1250 & 625 & 2500 \\
\hline \multicolumn{6}{|c|}{ PLEthanol } \\
\hline MIC & NT & 78 & NT & 156 & 78 \\
\hline MFC & NT & 156 & NT & 312 & 156 \\
\hline \multicolumn{6}{|c|}{ Piperine } \\
\hline MIC & 78 & 78 & 39 & 78 & 312 \\
\hline MFC & 156 & 156 & 78 & 156 & 625 \\
\hline \multicolumn{6}{|c|}{ Piperlongumine } \\
\hline $\mathrm{MIC}$ & 156 & 39 & 156 & 78 & 312 \\
\hline MFC & 312 & 78 & 312 & 156 & 625 \\
\hline \multicolumn{6}{|c|}{ Amphotericin B } \\
\hline MIC & 0.48 & 0.48 & 0.48 & 0.48 & 0.97 \\
\hline \multicolumn{6}{|c|}{ Itraconazole } \\
\hline $\mathrm{MIC}$ & 0.97 & 15.6 & 0.97 & 0.48 & 0.48 \\
\hline
\end{tabular}

464 For Candida tropicalis, the methanol fruit extract gave the largest inhibition zone (IZ $21.3 \mathrm{~mm}$ ) and 465 a MIC value of $39 \mu \mathrm{g} / \mathrm{mL}$. The MIC value for piperine against this fungus was $78 \mu \mathrm{g} / \mathrm{mL}$ and thus 466 was less effective than the methanol fruit extract. Piperine has been reported to be one of the main 467 piperamide compounds found in $P$. guineense (Scott et al., 2005). Our result could indicate that 468 some other piperamide compounds in the methanol fruit extract could be responsible for the good 469 growth inhibitory effects of the extract, or then that these compounds act in synergy together with 470 piperine to produce a lower MIC than that of pure piperine. The other extracts of the fruits were 471 moderately active against $C$. tropicalis with inhibition zones ranging from 19.8 to $11.0 \mathrm{~mm}$ (Table 
4). The methanol leaf extract was also active against the fungus with a MIC of $78 \mu \mathrm{g} / \mathrm{mL}$. The MIC value of the ethanol fruit and leaf extracts was found to be $78 \mu \mathrm{g} / \mathrm{mL}$ for both. In contrast to the other extracts, the decoctions and macerations showed no growth inhibition against $C$. tropicalis. All extracts, except for the macerations and decoctions were active against $C$. parapsilopsis with MIC values ranging from 312 to $625 \mu \mathrm{g} / \mathrm{mL}$. The largest inhibition zone of $28.7 \mathrm{~mm}$ and $18.0 \mathrm{~mm}$ were recorded for a methanol leaf and fruit extract, respectively. A mixture of methanoldichloromethane $(3: 1 \mathrm{v} / \mathrm{v})$ of the fruit extract of $P$. guineense has been previously found to be active against this fungus with a MIC value of $625 \mu \mathrm{g} / \mathrm{mL}$ (Dzoyem et al., 2014). Our result indicates that pure methanol is a better extractant for antifungals than methanol-dichloromethane $(3: 1)$, since we recorded a larger inhibition zone of $28.7 \mathrm{~mm}$ and a lower MIC value of $312 \mu \mathrm{g} / \mathrm{mL}$ with the methanol leaf extract compared to Dzoyem et al., (2014). The growth inhibitory effect of the ethanol extracts were not tested against $C$. parapsilopsis due to lack of material. Piperine and piperlongumine were active against $C$. parapsilosis with inhibition zones of 23.3 and $16.3 \mathrm{~mm}$, respectively. The MIC values for piperine and piperlongumine were found to be $39 \mu \mathrm{g} / \mathrm{mL}$ and 156 $\mu \mathrm{g} / \mathrm{mL}$, respectively. Thus, piperine could be responsible for some of the good activity displayed by the methanol leaf extract.

In our study, $P$. guineense extracts were active against Cryptococcus neoformans. The largest inhibitory activity was observed with the ethanol leaf and fruit extracts (23.8 $\mathrm{mm}$ and $22.2 \mathrm{~mm}$ ) (Table 4). The MIC values for the ethanol leaf and fruit extracts were in agreement with the agar diffusion result ( $78 \mu \mathrm{g} / \mathrm{mL}$ and $156 \mu \mathrm{g} / \mathrm{mL}$ respectively). The methanol leaf and fruit extracts recorded inhibition zones of $21.3 \mathrm{~mm}$ and $19.7 \mathrm{~mm}$ respectively, and their MIC values were recorded to be $156 \mu \mathrm{g} / \mathrm{mL}$ for both. It was observed that the leaf extracts of $P$. guineense were more active against this fungus than the fruits extracts. The chloroform fruit and leaf extracts were active against the fungus with inhibition zones of $18.2 \mathrm{~mm}$ and $17.3 \mathrm{~mm}$. The hexane fruit and leaf extracts were moderately active also (IZ $14.3 \mathrm{~mm}$ and $11.7 \mathrm{~mm}$ ). The MIC values for the chloroform and hexane extracts against this fungus were $156 \mu \mathrm{g} / \mathrm{mL}$ and $2500 \mu \mathrm{g} / \mathrm{mL}$, respectively. Our result is consistent with one previous report that $P$. guineense fruit extract has growth inhibitory activity against $C$. neoformans with a MIC of $312 \mu \mathrm{g} / \mathrm{mL}$ (Dzoyem et al., 2014). Piperine and piperlongumine were active with a MIC of $312 \mu \mathrm{g} / \mathrm{mL}$ for both.

\section{Conclusion}

$P$. guineense extracts, piperine and piperlongumine have been found to possess interesting antifungal properties as recorded in this study. The antifungal efficacy of the methanol, ethanol, 
chloroform and $n$-hexane extracts of the fruit and leaf of $P$. guineense, as well as piperine and piperlongumine on various $C$. albicans and non- albicans Candida strains supports the use of $P$. guineense in the treatment of fungal infections in traditional medicine and demonstrates that extracts from this plant could contain bioactive compounds that could be utilized as therapeutic agents or scaffolds for the production of new antifungal drugs to treat diseases associated with Candida species and Cryptococcus neoformans. The study demonstrated that the extracts and piperamide compounds exert promising antifungal properties against pathogenic Candida albicans and other non-albicans Candida strains. Moreover, various extracts, especially from P. guineense leaves, showed a promising growth inhibitory profile against Cryptococcus neoformans which is known to cause life-threatening meningitis in immunocompromised individuals. In view of this current knowledge on alkaloids of $P$. guineense as antifungal agents, we recommend that additional research should be done to evaluate the in vivo antifungal properties of the extracts and piperamide compounds from $P$. guineense with some animal models. The marked inhibitory activity recorded with piperine and piperlongumine against $C$. albicans revealed that they could be good antifungal agents. Further research is needed to evaluate the inhibitory activity of these piperamide compounds in combination with currently known standard antibiotics because piperine and piperlongumine could possibly enhance the effects of the currently available antifungal drugs for the treatment of fungal infections. This study has clarified and broadened the traditional knowledge on the uses of $P$. guineense as an antifungal remedy in African traditional medicine. Systematic studies are in progress and for further investigations, HPLC-DAD and UHPLC/Q-TOF MS analysis are currently being conducted by our research team to characterize and identify the compounds present in the extracts with promising antifungal activity.

\section{Author's contributions}

E.E.M, Y.H, P.F, H.V, and C.A designed the experiment.

E.E.M and C.A conducted the field work, ethnobotanical survey and documentations in Nigeria. E.E.M, Y.H, H.V and P.F performed the in vitro antifungal screening and MIC estimations. The manuscript was first drafted by E.E.M, C.A, and P.F. The manuscript was further revised and corrected by H.V, Y.H and P.F. All the authors have read, agreed and approved the final version of the manuscript.

\section{Conflict of interest}

The authors indicate no potential conflicts of interest. 
541 The ethical consideration of the project was done appropriately according to the authors' institution 542 and was approved by the institutional ethics committee. The ethnobotanical survey was done with 543 the approval of the village heads and according to the national institutional rules of the indigenous 544 people.

545

546

\section{Acknowledgement}

The authors are grateful to the Faculty of Pharmacy, Division of Pharmaceutical Biosciences, University of Helsinki and Department of Food Science and Technology, School of Engineering and Engineering Technology, Federal University of Technology Owerri, Imo state, Nigeria for supporting this work. The first and last authors acknowledge the financial support from Ekhaga foundation (project grant number 2017-7), Sweden. The authors are grateful to the traditional healers and herb sellers for giving their time.

\section{Appendix A. Supplementary material}

Questionnaire used for the ethnobotanical survey on the traditional use of Piper guineense for the treatment of fungal infections in Imo state, South Eastern Nigeria.

We are researchers from the University of Helsinki, Finland and Federal University of Technology Owerri, Imo state, Nigeria. We would like to know the various methods that you use for utilization of Uziza (Piper guineense) for the treatment of fungal infections.

\section{Gender Male $\square \quad$ Female}

2. What is your name (optional)

3. What is your major occupation?: a). Herbalist

b). Traditional medical practitioner

c). Traditional healer/ herb seller

d). Other
4. What is your age? :
a). 20-35
$36-55$
$56-75$

5. For how long have you been practicing traditional medicine? : a) $1-15$ years

$$
16-30 \text { years } \square \quad 31 \text { years and above } \square
$$

6. What is your source of knowledge of traditional medicine? : a). Inherited/learnt from parents

$$
\text { Training from other herbalists } \square \quad \text { Other } \square
$$

7. What is your level of education? : a). University education $\square \quad$ High school $\square$ Primary education $\square \quad$ No formal education $\square$ 
9. Can you name some of the fungal diseases that you treat with Uziza (Piper guineense)?

10. How often do you treat these diseases?

11. What are the symptoms and how do you diagnose this fungal infections?

\begin{tabular}{|l|l|l|}
\hline Fungal infections & Local name & $\begin{array}{l}\text { Method of diagnosis/ } \\
\text { symptoms }\end{array}$ \\
\hline & & \\
\hline & & \\
\hline & & \\
\hline & & \\
\hline & & \\
\hline & & \\
\hline & & \\
\hline
\end{tabular}

12. Which part of the plant do you often use?: Fruit $\square \quad$ Leaves $\square \quad$ Roots $\square$ Other $\square$

13. How do you get the Piper guineense used for the treatment? : a) Cultivate them $\square \quad$ b) Buy from the market $\square \quad$ c) Collect from the wild forest and bushes $\square \quad$ d) Other $\square$

14. What are the method of preparations and administrations?

\begin{tabular}{|l|l|l|}
\hline Fungal diseases & Method of preparation & Mode of administration \\
\hline & & \\
\hline & & \\
\hline & & \\
\hline & & \\
\hline & & \\
\hline & & \\
\hline
\end{tabular}

573 15. What are the dosage of administration and how long does the treatment last? 
16. What do you do if you observe that the patient is not responding to your antifungal treatment?

576

Do you have some general comment about the possible challenges you face in your daily treatment of fungal infections using Piper guineense extracts?

Thank you for your cooperation.

\section{References}

Abiala, M.A., Ayandeko, F.M., Odebode, A.C., 2015. Antifungal effects of selected botanicals on fungal pathogens of watermelon fruit. Arch. Phytopathol. Plant Prot. 48, 569-577.

Abila, B., Richens, A., Davies, J., 1993. Anticonvulsant effects of extracts of the West African black pepper, Piper guineense. J. Ethnopharmacol. 39, 113-117.

Abdelgadir, H. A., and Van Staden, J., 2013. Ethnobotany, ethnopharmacology and toxicity of Jatropha curcas L.(Euphorbiaceae): A review. S. Afr. J. Bot, 88, 204-218.

Adesina, S.K., Adebayo, A.S., Adesina, S.K., Groning, R., 2003. New constituents of Piper guineense fruit and leaf. Die Pharmazie. 58, 423-425.

Agyare, C., Spiegler, V., Asase, A., Scholz, M., Hempel, G., Hensel, A., 2018. An ethnopharmacological survey of medicinal plants traditionally used for cancer treatment in the Ashanti region, Ghana. J. Ethnopharmacol. 212, 137-152.

Ajibesin, K., Bala, D.N., Umoh, U.F., 2011. The use of medicinal plants to treat sexually transmitted diseases in Nigeria: Ethnomedicinal survey of Niger Delta Region. Int. J. Green Pharm. (IJGP). 5, 3.

Anyanwu, C., Nwosu, G., 2014. Assessment of the antimicrobial activity of aqueous and ethanolic extracts of Piper guineense leaves. J. Med. Plants Res. 8, 436-440.

Asase, A., Hesse, D.N., Simmonds, M.S., 2012. Uses of multiple plants prescriptions for treatment of malaria by some communities in southern Ghana. J. Ethnopharmacol. 144, 448-452.

Asawalam, E., 2006. Insecticidal and repellent properties of Piper guineense seed oil extract for the control of maize weevil, Sitophilus zeamais. Electron. J. Environ. Agric. Food Chem. 5, 1389-1394.

Besong, E.E., Balogun, M.E., Djobissie, S.F., Mbamalu, O.S., Obimma, J.N., 2016. A review of Piper guineense (African Black Pepper). Int. J. Pharm. Pharm. Res. 6, 368-384. 
Brown, A.J., Brown, G.D., Netea, M.G., Gow, N.A., 2014. Metabolism impacts upon Candida immunogenicity and pathogenicity at multiple levels. Trends Microbiol. 22, 614-622.

Cheikhyoussef, A., Shapi, M., Matengu, K., Ashekele, H.M., 2011. Ethnobotanical study of indigenous knowledge on medicinal plant use by traditional healers in Oshikoto region, Namibia. J. Ethnobiol. Ethnomed. 7, 10.

Cockerill, F.R., Wikler, M., Bush, K., Dudley, M., Eliopoulos, G., Hardy, D., 2012. Clinical and Laboratory Standards Institute. Performance standards for antimicrobial susceptibility testing: twenty-second informational supplement. Approved Standard-Ninth Edition. 950 West Valley Road, Suite 2500, Wayne, Pennsylvania 19087, USA.

Dada, A.A., Ifesan, B.O.T., Fashakin, J.F., 2013. Antimicrobial and antioxidant properties of selected local spices used in "Kunun" beverage in Nigeria. Acta Sci. Pol. Technol. Aliment. 12, 373-378.

Dzoyem, J. P., Kuete, V., 2013. Review of the antifungal potential of African medicinal plants. In Antifungal Metabolites from Plants pp. 79-153. Springer, Berlin, Heidelberg.

Dzoyem, J.P., Tchuenguem, R.T., Kuiate, J.R., Teke, G.N., Kechia, F.A., Kuete, V., 2014. In vitro and in vivo antifungal activities of selected Cameroonian dietary spices. BMC Complement. Altern. Med. 14, 58.

Ebana, R., Edet, U., Ekanemesang, U., Ikon, G., Etok, C., Edet, A., 2016. Antimicrobial activity, phytochemical screening and nutrient analysis of Tetrapleura tetraptera and Piper guineense. Asian J. Med. Health. 1, 1-8.

Ejele, A., Duru, I., Oze, R., Iwu, I., Ogukwe, C., 2012. Comparison of antimicrobial potential of Piper umbellatum, Piper guineense, Ocimum gratissimum and Newbouldia laevis extracts. Int. Res. J. Biochem. Bioinform. 2, 35-40.

Fabricant, D.S., Farnsworth, N.R., 2001. The value of plants used in traditional medicine for drug discovery. Environ. Health Perspect. 109 Suppl 1, 69-75.

Freiesleben, S.H., Soelberg, J., Jäger, A.K., 2015. Medicinal plants used as excipients in the history in Ghanaian herbal medicine. J. Ethnopharmacol. 174, 561-568.

Fyhrquist, P., Laakso, I., Marco, S.G., Julkunen-Tiitto, R., Hiltunen, R., 2014. Antimycobacterial activity of ellagitannin and ellagic acid derivate rich crude extracts and fractions of five selected species of Terminalia used for treatment of infectious diseases in African traditional medicine. S. Afr. J. Bot. 90, 1-16.

Gbekley, H.E., Katawa, G., Karou, S.D., Anani, S., Tchadjobo, T., Ameyapoh, Y., Batawila, K., Simpore, J., 2016. Ethnobotanical study of plants used to treat asthma in the maritime region in Togo. Afr. J. Trad. Complement. Altern. Med. 14, 196-212.

Gulshan, K., Moye-Rowley, W.S., 2007. Multidrug resistance in fungi. Eukaryot. Cell. 6, 19331942. 
Ibrahim, J., Muazzam, I., Jegede, I., Kunle, O., 2010. Medicinal plants and animals sold by the Yan-Shimfidas of Sabo Wuse in Niger State, Nigeria. Afr. J. Pharm. Pharmacol. 4, 386-394.

Konning, G., Agyare, C., Ennison, B., 2004. Antimicrobial activity of some medicinal plants from Ghana. Fitoterapia. 75, 65-67.

Mario, D.A.N., Denardi, L.B., Bandeira, L.A., Antunes, M.S., Santurio, J.M., Severo, L.C., Alves, S.H., 2012. The activity of echinocandins, amphotericin B and voriconazole against fluconazolesusceptible and fluconazole-resistant Brazilian Candida glabrata isolates. Mem. Inst. Oswaldo Cruz. 107, 433-436.

Maroyi, A., 2013. Traditional use of medicinal plants in south-central Zimbabwe: review and perspectives. J. Ethnobiol. Ethnomed. 9, 31.

Mgbeahuruike, E., Yrjönen, T., Vuorela, H., Holm, Y., 2017. Bioactive compounds from medicinal plants: Focus on Piper species. S. Afr. J. Bot. 112, 54-69.

Mgbeahuruike, E.E., Vuorela, H., Yrjonen, T., Holm, Y., 2018. Optimization of thin-layer chromatography and high-performance liquid chromatographic method for Piper guineense extracts. Nat. Prod. Commun. 13, 25-28.

Ngane, A.N., Biyiti, L., Bouchet, P., Nkengfack, A., Zollo, P.A., 2003. Antifungal activity of Piper guineense of Cameroon. Fitoterapia. 74, 464-468.

Ngarivhume, T., van't Klooster, C.I., de Jong, J.T., Van der Westhuizen, Jan H, 2015. Medicinal plants used by traditional healers for the treatment of malaria in the Chipinge district in Zimbabwe. J. Ethnopharmacol. 159, 224-237.

Obodozie, O.O., Ameh, S.J., Afolabi, E.K., Oyedele, E.O., Ache, T.A., Onanuga, C.E., Ibe, M.C., Inyang, U.S., 2010. A normative study of the components of niprisan - an herbal medicine for sickle cell anaemia. J. Diet. Suppl. 7, 21-30.

Ogunniran, K.O., 2009. Antibacterial effects of extracts of Ocimum gratissimum and piper guineense on Escherichia coli and Staphylococcus aureus. Afr. J. Food Sci. 3, 77-81.

Okigbo, R., Igwe, D., 2007. Antimicrobial effects of Piper guineense 'Uziza'and Phyllantus amarus 'Ebe-benizo'on Candida albicans and Streptococcus faecalis. Acta Microbiol. Immunol. Hung. 54, 353-366.

Osuchukwu, N.C., Eko, J.E., Abia, R.P., Ochei, K.C., 2017. Use of herbal medicine among adult residents in Calabar metropolis, Cross River State, Nigeria. J. Complement. Altern. Med. Res. 2, 114.

Oyemitan, I. A., Olayera, O. A., Alabi, A., Abass, L. A., Elusiyan, C. A., Oyedeji, A. O., \& Akanmu, M. A. 2015. Psychoneuropharmacological activities and chemical composition of essential oil of fresh fruits of Piper guineense (Piperaceae) in mice. J. Ethnopharmacol, 166, 240249. 
Park, B.J., Wannemuehler, K.A., Marston, B.J., Govender, N., Pappas, P.G., Chiller, T.M., 2009. Estimation of the current global burden of Cryptococcal meningitis among persons living with HIV/AIDS. AIDS (London, England). 23, 525-530.

Pfaller, M.A., Diekema, D.J., 2007. Epidemiology of invasive candidiasis: a persistent public health problem. Clin. Microbiol. Rev. 20, 133-163.

Pfaller, M.A., Diekema, D.J., 2004. Rare and emerging opportunistic fungal pathogens: concern for resistance beyond Candida albicans and Aspergillus fumigatus. J. Clin. Microbiol. 42, 4419-4431.

Rahmatullah, M., Hossan, S., Khatun, A., Seraj, S., Jahan, R., 2012. Medicinal plants used by various tribes of Bangladesh for treatment of malaria. Malar. Res. Treat. 2012, 371798.

Salih, E., Kanninen, M., Sipi, M., Luukkanen, O., Hiltunen, R., Vuorela, H., Julkunen-Tiitto, R., Fyhrquist, P., 2017. Tannins, flavonoids and stilbenes in extracts of African savanna woodland trees Terminalia brownii, Terminalia laxiflora and Anogeissus leiocarpus showing promising antibacterial potential. S. Afr. J. Bot. 108, 370-386.

\section{Sandberg, F., Perera-Ivarsson, P., El-Seedi, H.R., 2005. A Swedish collection of medicinal plants} from Cameroon. J. Ethnopharmacol. 102, 336-343.

Scott, I.M., Puniani, E., Jensen, H., Livesey, J.F., Poveda, L., Sánchez-Vindas, P., Durst, T., Arnason, J.T., 2005. Analysis of Piperaceae germplasm by HPLC and LCMS: a method for isolating and identifying unsaturated amides from Piper spp extracts. J. Agric. Food Chem. 53, 1907-1913.

Walker, L.A., Gow, N.A., Munro, C.A., 2013. Elevated chitin content reduces the susceptibility of Candida species to caspofungin. Antimicrob. Agents Chemother. 57, 146-154. 